\title{
Adaption and recovery of Nitrosomonas europaea to chronic TiO2 nanoparticle exposure
}

Wu, Junkang; Zhan, Manjun; Chang, Yan; Su, Qingxian; Yu, Ran

Published in:

Water Research

Link to article, DOI:

10.1016/j.watres.2018.09.043

Publication date:

2018

Document Version

Peer reviewed version

Link back to DTU Orbit

Citation (APA):

Wu, J., Zhan, M., Chang, Y., Su, Q., \& Yu, R. (2018). Adaption and recovery of Nitrosomonas europaea to chronic $\mathrm{TiO}_{2}$ nanoparticle exposure. Water Research, 147, 429-439.

https://doi.org/10.1016/j.watres.2018.09.043

\section{General rights}

Copyright and moral rights for the publications made accessible in the public portal are retained by the authors and/or other copyright owners and it is a condition of accessing publications that users recognise and abide by the legal requirements associated with these rights.

- Users may download and print one copy of any publication from the public portal for the purpose of private study or research.

- You may not further distribute the material or use it for any profit-making activity or commercial gain

- You may freely distribute the URL identifying the publication in the public portal 


\section{Accepted Manuscript}

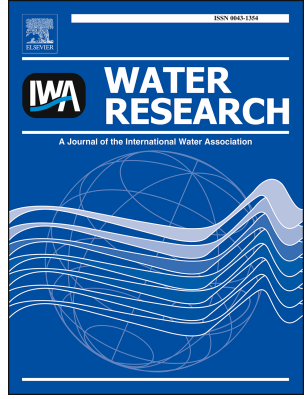

Adaption and recovery of Nitrosomonas europaea to chronic $\mathrm{TiO}_{2}$ nanoparticle exposure

Junkang Wu, Manjun Zhan, Yan Chang, Qingxian Su, Ran Yu

PII: $\quad$ S0043-1354(18)30758-9

DOI: $\quad$ 10.1016/j.watres.2018.09.043

Reference: WR 14093

To appear in: Water Research

Received Date: 18 May 2018

Revised Date: 24 September 2018

Accepted Date: 25 September 2018

Please cite this article as: Wu, J., Zhan, M., Chang, Y., Su, Q., Yu, R., Adaption and recovery of Nitrosomonas europaea to chronic $\mathrm{TiO}_{2}$ nanoparticle exposure, Water Research (2018), doi: https:// doi.org/10.1016/j.watres.2018.09.043.

This is a PDF file of an unedited manuscript that has been accepted for publication. As a service to our customers we are providing this early version of the manuscript. The manuscript will undergo copyediting, typesetting, and review of the resulting proof before it is published in its final form. Please note that during the production process errors may be discovered which could affect the content, and all legal disclaimers that apply to the journal pertain. 


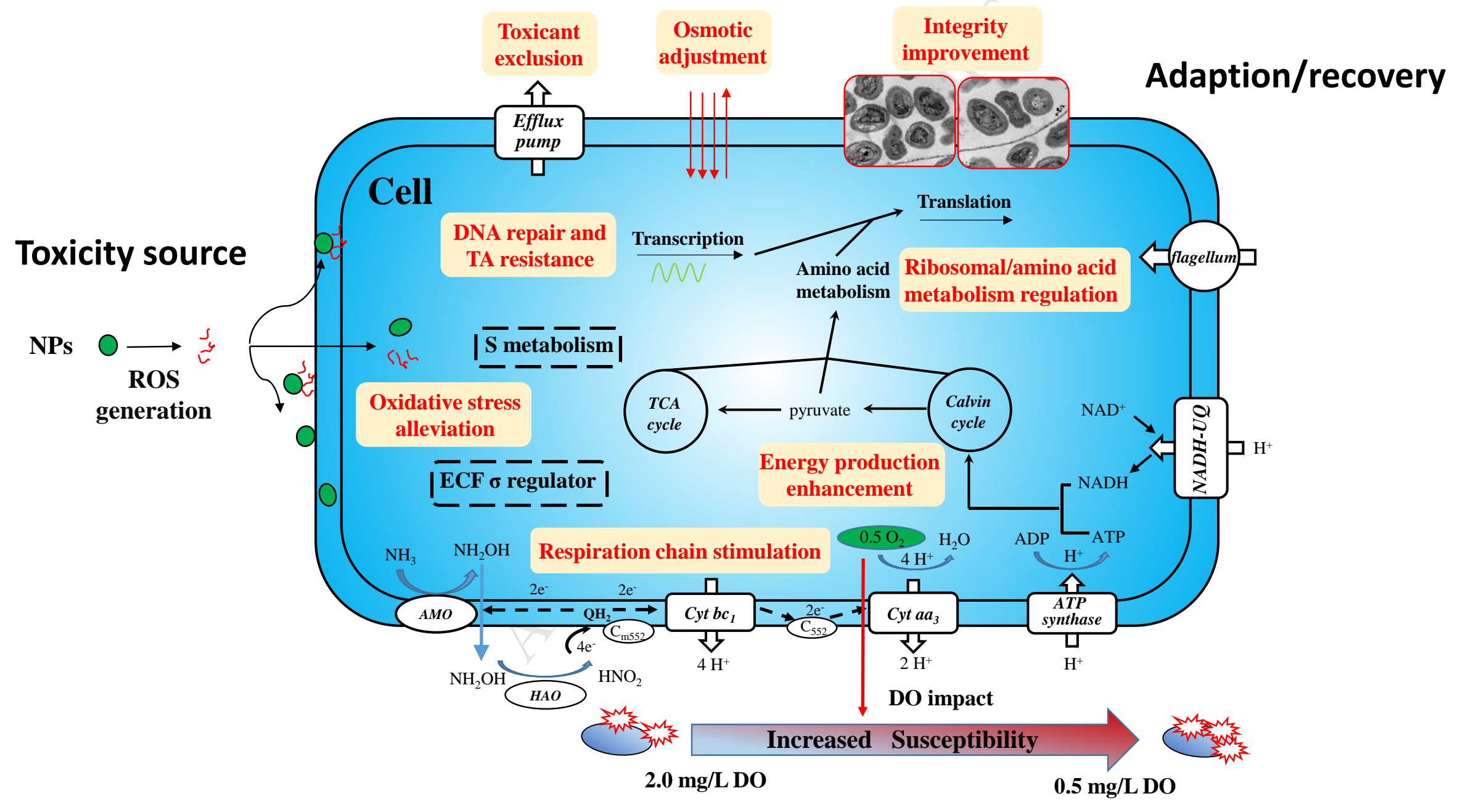




\section{TITLE PAGE}

\section{Adaption and recovery of Nitrosomonas europaea to chronic $\mathrm{TiO}_{2}$}

\section{nanoparticle exposure}

Junkang $\mathrm{Wu}^{1,2,3}$, Manjun $\mathrm{Zhan}^{4}$, Yan Chang ${ }^{1,2}$, Qingxian $\mathrm{Su}^{3}$, Ran $\mathrm{Yu}^{* 1,2}$

1. Department of Environmental Science and Engineering, School of Energy and Environment,

Wuxi Engineering Research Center of Taihu Lake Water Environment, Southeast University, Nanjing, Jiangsu, China 210096

2. Key Laboratory of Environmental Medicine Engineering, Ministry of Education, Southeast University, Nanjing, Jiangsu, China 210009

3. Department of Environmental Engineering, Technical University of Denmark, Lyngby, Denmark 2800

4. Nanjing Research Institute of Environmental Protection, Nanjing Environmental Protection Bureau, Nanjing, Jiangsu, China 210013

* Corresponding author:

Ran Yu, Department of Environmental Science and Engineering, School of Energy and Environment, Southeast University, No.2 Sipailou Street, Nanjing, 210096, China; Phone: (+86) 15312083786; Fax: (+86) 25 83792614; email: yuran@seu.edu.cn 
1 Abstract: Although the adverse impacts of emerging nanoparticles (NPs) on the biological

2 nitrogen removal (BNR) process have been broadly reported, the adaptive responses of

3 NP-impaired nitrifiers and the related mechanisms have seldom been addressed to date. Here, we systematically explored the adaption and recovery capacities of the ammonia oxidizer Nitrosomonas europaea under chronic $\mathrm{TiO}_{2} \mathrm{NP}$ exposure and different dissolved oxygen (DO) conditions at the physiological and transcriptional levels in a chemostat reactor, N. europaea cells adapted to $50 \mathrm{mg} / \mathrm{L} \mathrm{TiO}_{2} \mathrm{NP}$ exposure after 40-d incubation and the inhibited cell growth, membrane integrity, nitritation rate, and ammonia monooxygenase activity all recovered regardless of the DO concentrations. Transmission electron microscope imaging indicated the remission of the membrane distortion after the cells' 40-d adaption to the NP exposure. The microarray results further suggested that the metabolic processes associated with the membrane repair were pivotal for cellular adaption/recovery, such as the membrane efflux for toxicant exclusion, the structural preservation or stabilization, and the osmotic equilibrium adjustment. In addition, diverse metabolic and stress-defense pathways, including aminoacyl-tRNA biosynthesis, respiratory chain, ATP production, toxin-antitoxin 'stress-fighting', and DNA repair were activated for the cellular adaption coupled with the metabolic activity recovery, probably via recovering the energy production/conversion efficiency and mediating the non-photooxidative stress. Finally, low DO $(0.5 \mathrm{mg} / \mathrm{L})$ incubated cells were more susceptible to $\mathrm{TiO}_{2} \mathrm{NP}$ exposure and required more time to adapt to and recover from the stress, which was probably due to the stimulation limitation of the oxygen-dependent energy metabolism with a lower oxygen supply. The findings of this study provide new insights into NP contamination control and management adjustments during the BNR process.

Keywords: $\mathrm{TiO}_{2}$ nanoparticle; Nitrosomonas europaea; dissolved oxygen; adaption; 


\section{6 microarray}

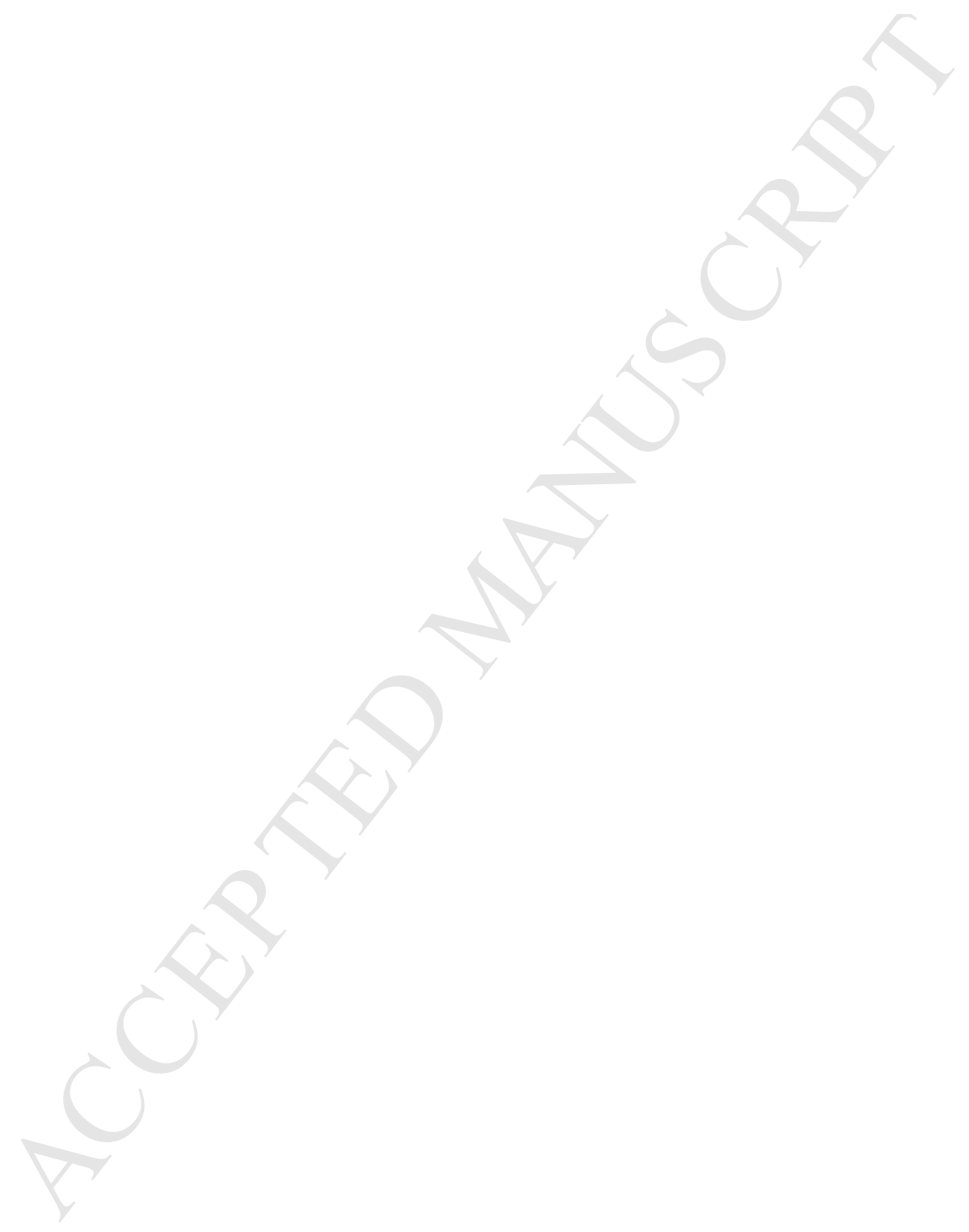




\section{Introduction}

Metal oxide nanomaterials characterized by sizes smaller than $100 \mathrm{~nm}$ in at least one dimension are extensively used in many commercial and industrial fields owing to their unique physico-chemical properties (Vance et al. 2015). Titanium oxide nanoparticles $\left(\mathrm{TiO}_{2} \mathrm{NPs}\right.$ ) with high photocatalytic, ultraviolet shielding, and antibacterial activities are widely found in cosmetics, textiles, sunscreens, photo-catalysts, and lithium batteries (Minetto et al. 2014). $\mathrm{TiO}_{2} \mathrm{NPs}$ are the most widely used nanomaterials worldwide and their production has rapidly increased to 10,000 tons per year during 2011-2014 (Piccinno et al. 2012) and is expected to reach 2.5 million tons per year by 2025 (Robichaud et al. 2009). Due to their extensive application, $\mathrm{TiO}_{2} \mathrm{NPs}$ are inevitably released into the environment and are recognized as an emerging environmental stressor (Gondikas et al. 2014). As a result, the negative impacts of $\mathrm{TiO}_{2} \mathrm{NPs}$ on animal cells (Yu et al. 2017), aquatic organisms (Hu et al. 2017), bacterial cells (Liu et al. 2016), plants (Zahra et al. 2017), and biofilm communities (Binh et al. 2016) have been widely recognized and have raised increasing concerns regarding their biosafety and biosecurity in ecosystems.

Recently, the release of engineered $\mathrm{TiO}_{2} \mathrm{NPs}$ into biological wastewater treatment plants (WWTPs) has drawn significant attention (Polesel et al. 2018; Zhou et al. 2015). $\mathrm{TiO}_{2} \mathrm{NP}$ associated $\mathrm{Ti}$ concentrations of $181-1233 \mu \mathrm{g} / \mathrm{L}$ were detected in the raw sewage of 10 representative WWTPs in the US (Westerhoff et al. 2011). $\mathrm{The}^{\mathrm{TiO}_{2}} \mathrm{NP}$ concentrations in the effluents of European WWTP were estimated to have increased from $2.5-10.8 \mu \mathrm{g} / \mathrm{L}$ in 2009 to $13-$ $110 \mu \mathrm{g} / \mathrm{L}$ in 2013 (Sun et al. 2014; Gottschalk et al. 2009). The increased production and usage of $\mathrm{TiO}_{2}$ NPs will inevitably cause the occurrence of higher NP concentrations in WWTPs in the near future. As a result, the diverse microorganisms used for pollutant removal in WWTPs are potentially threatened by the $\mathrm{TiO}_{2} \mathrm{NPs}$ due to their bio-toxicities. $\mathrm{TiO}_{2}$ NPs have been reported to reduce the bacterial abundances or microbial community diversities, depress the activities of ammonia monooxygenase (AMO), nitrite oxidoreductase, exopolyphosphatase, and polyphosphate kinase, and thus inhibit organic matter degradation processes and decrease the nitrogen and 
phosphorus removal efficiencies in WWTPs (Li et al. 2017; Li et al. 2016; Zhang et al. 2018). The nitrogen removal process is generally more susceptible to NP-caused stress than the phosphorus removal process. During a 70-d operation of a sequencing batch reactor (SBR) with a concentration of $50 \mathrm{mg} / \mathrm{L} \mathrm{TiO}_{2}$ NPs in the influent, the nitrogen removal rate was significantly retarded by $69.6 \%$ whereas the phosphorus removal efficiencies remained constant (Zheng et al. 2011a). As the rate-limiting and first nitrification step in a biological nitrogen removal (BNR) system, the ammonia oxidation process (nitritation) performed by ammonia-oxidizing bacteria (AOB) is vulnerable to NP stress. Zheng et al. (2011a) and Yang et al. (2013) have discovered the high sensitivity of the ammonia oxidation process to $\mathrm{TiO}_{2}$ or Ag NP-caused stress in the BNR systems.

Currently, the $\mathrm{TiO}_{2}$ NP toxicity has been acknowledged to be caused by oxidative stress due to the reactive oxygen species (ROS) generation and physical interruption when NPs are adsorbed onto the cell membrane or internalized into the cells (Huang et al. 2017; Li et al. 2012; Liu et al. 2009). Nevertheless, most research studies have mainly focused on the acute or batch exposure effects to cell respiration, microbial diversity, or wastewater treatment performances (Li et al. 2017; Zheng et al. 2011a; Li et al. 2015). Few studies have investigated the mechanisms of the metabolic and transcriptional regulations of nitrifiers in response to chronic $\mathrm{TiO}_{2} \mathrm{NP}$ exposure in a continuous flow bioreactor. In addition, self-adaptive regulations or the self-recovery potential of NP-impaired nitrifiers and the associated mechanisms have been seldom addressed to date, which are crucial for developing emergency adjustment strategies in response to NP-impacted wastewater treatment biosystems. Only our previous study addressed these issues and we discovered the recovery potentials of $\mathrm{ZnO}$ NP-impaired $\mathrm{AOB}$ and the associated regulation pathways including membrane fixation, heavy metal resistance, toxin-antitoxin defense, and oxidative phosphorylation after 6-h recovery during batch incubation (Wu et al. 2017).

It is noteworthy that $\mathrm{AOB}$ are highly sensitive to many environmental factors including dissolved oxygen (DO) levels (Prosser 1990). In addition, we have found that oxygen oxidation-dependent electron transfer pathways were actively involved in the stress response of $N$. 
europaea cells to $\mathrm{ZnO} \mathrm{NP}$ exposure (Wu et al. 2017). Therefore, the DO level could potentially affect the NP toxicity effects to N. europaea, which is a typical chemolithotrophic AOB and widely exists in BNR processes (Kowalchuk and Stephen 2001). In this study, we hypothesized that $N$. europaea cells have adaption and recovery capacities in response to chronic $\mathrm{TiO}_{2} \mathrm{NP}$ stress and that the DO level is a key factor affecting their adaption capacities. To test these hypotheses, the physiological and metabolic responses of the continuously cultivated N. europaea to chronic $\mathrm{TiO}_{2}$ NP stress under both aerobic and microaerobic conditions were compared and the recovery capacities of the NP-impaired cells were further assessed. Genome-wide microarray and quantitative reverse-transcriptase polymerase chain reaction (qRT-PCR) techniques were used for the exploration of the transcriptional regulations of the NP-impaired $N$. europaea cells, as well as the associated adaptive regulation and recovery mechanisms.

\section{Materials and Methods}

\subsection{Chemostat bioreactor operation}

N. europaea (ATCC 19718) was continuously cultivated in a stirred chemostat bioreactor with a $3 \mathrm{~L}$ working volume (hydraulic retention time: $2.2 \mathrm{~d}$ ) at $25{ }^{\circ} \mathrm{C}$ in the dark. The $\mathrm{DO}$ concentration was maintained at $2.0 \pm 0.2$ or $0.5 \pm 0.2 \mathrm{mg} / \mathrm{L}$ by filter-sterilized air aeration. The $\mathrm{pH}$ in the reactor was maintained at $7.50 \pm 0.10$ by the automatic introduction of a saturated sterilized $\mathrm{NaHCO}_{3}$ buffer with a Meller $\mathrm{pH}$ controller (Taiwan, China). The cultivation medium was similar to that used in a previous study ( $\mathrm{Yu}$ et al. 2015) and contained $10 \mathrm{mM}\left(\mathrm{NH}_{4}\right)_{2} \mathrm{SO}_{4}, 10 \mathrm{mM}$ 3-[4-(2-Hydroxyethyl)-1-piperazine] propanesulfonic acid, $0.8 \mathrm{mM} \mathrm{MgSO}_{4} \cdot 7 \mathrm{H}_{2} \mathrm{O}, 0.5 \mathrm{mM}$ of $\mathrm{K}_{2} \mathrm{HPO}_{4}, 0.1 \mathrm{mM}$ of $\mathrm{CaCl}_{2} \cdot 2 \mathrm{H}_{2} \mathrm{O}, 2.4 \mu \mathrm{M}$ EDTA-Fe ${ }^{3+}, 1 \mu \mathrm{M} \mathrm{CuSO}_{4} \cdot 5 \mathrm{H}_{2} \mathrm{O}, 0.9 \mu \mathrm{M}$ of $\mathrm{MnCl}_{2} \cdot 4 \mathrm{H}_{2} \mathrm{O}, 0.4 \mu \mathrm{M} \mathrm{Na} 2 \mathrm{MoO}_{4} \cdot 2 \mathrm{H}_{2} \mathrm{O}, 0.3 \mu \mathrm{M} \mathrm{ZnSO}{ }_{4} \cdot 7 \mathrm{H}_{2} \mathrm{O}$, and $0.02 \mu \mathrm{M} \mathrm{CoCl}_{2} \cdot 6 \mathrm{H}_{2} \mathrm{O}$.

\subsection{Nanoparticle characterization}

The anatase $\mathrm{TiO}_{2}$ NPs were bought from Sigma Company (St. Louis, MO, USA). A JSM-6390A scanning electron microscope (SEM) (Japan Electronics Co., Ltd, Japan) was used to 
characterize the primary size of the NPs. The average hydrodynamic diameter with a refractive

106 index of 1.43 and the $\zeta$ potential of the $\mathrm{TiO}_{2}$ NP suspension in Mill-Q water was determined by dynamic light scattering (DLS) using a Malvern Nano ZS90 analyzer (Malvern, United Kingdom). Prior to the measurements, the $\mathrm{TiO}_{2} \mathrm{NP}$ suspension was subject to ultrasonic dispersion for $15 \mathrm{~min}$ $(50 \mathrm{kHz}, 16 \mathrm{~W})$.

\subsection{Exposure experiment setup}

The $\mathrm{TiO}_{2}$ NPs with a concentration of 1 or $50 \mathrm{mg}$ NPs/L were added to the reactor to investigate their chronic impacts on $N$. europaea cultivated either at 0.5 or $2.0 \mathrm{mg} \mathrm{DO} / \mathrm{L}$. The 1 $\mathrm{mg} / \mathrm{L} \mathrm{TiO}{ }_{2} \mathrm{NP}$ concentration was chosen to mimic the environmental-relevant value before entering the WWTPs (Westerhoff et al. 2011). The effects of $50 \mathrm{mg} / \mathrm{L} \mathrm{NPs}$ on the bioreactor performance were also assessed because the $\mathrm{TiO}_{2} \mathrm{NP}$ concentration may potentially increase in the near future due to the increased production and usage (Robichaud et al. 2009) and to ensure the detectability of the toxicity effects. Prior to the NP exposure experiments, each chemostat reactor was operated for at least four weeks to ensure stable performances as the baseline control. The $\mathrm{NH}_{4}{ }^{+}{ }^{-} \mathrm{N}, \mathrm{NO}_{2}{ }^{-}-\mathrm{N}$, cell density, and AMO activities were monitored every day and were generally around $3 \mathrm{mg} / \mathrm{L}, 267$ $\mathrm{mg} / \mathrm{L}, 3.0^{*} 10^{8}$ cell $/ \mathrm{mL}$, and $0.98 \mu \mathrm{g}$ nitrite $/ \mathrm{mg}$ protein $/ \mathrm{min}$, respectively. At the beginning of the NP exposure experiment, the $\mathrm{TiO}_{2} \mathrm{NPs}$ were introduced to the bioreactor and the influent at the final concentrations of 1 or $50 \mathrm{mg} / \mathrm{L}$ respectively. The cultures were sampled at the designated time points $(0,3,6,12$, and $48 \mathrm{~h}$ during the first $2 \mathrm{~d}$, every $2 \mathrm{~d}$ during the next $18 \mathrm{~d}$, and every $5 \mathrm{~d}$ until the end) throughout the 40-d exposure experiment.

\subsection{Analytical procedures}

The $\mathrm{NH}_{4}{ }^{+}-\mathrm{N}$ and $\mathrm{NO}_{2}{ }^{-}-\mathrm{N}$ concentrations were determined using Standard Methods (SEPAC 2002). The cell concentration was quantified by a direct count with a bacterial counting chamber (Hausser Scientific Partnership, PA, USA) using a Nikon microscope (Nikon, Japan). The cell membrane integrity was examined with a fluorescence test using a LIVE/DEAD® ${ }^{\text {BacLight }}{ }^{\mathrm{TW}}$ Bacterial Viability Kit (Life Technologies, MA, USA) and following the manufacturer's instructions. 
The specific AMO enzyme activity for the ammonia oxidation was determined in terms of nitrite production rate per unit of protein using an optimized reporting method as described previously (Zheng et al. 2011b; Yu et al. 2016).

The cell morphological changes under chronic $\mathrm{TiO}_{2}$ NP stress (12-d and 40-d exposure) were assessed using a JEM-2100 transmission electron microscope (TEM) (Japan Electronics Co., Ltd, Japan) as described elsewhere (Yu et al. 2016). Briefly, the harvested cell pellets were fixed with 3$5 \%$ glutaraldehyde, dehydrated in $50,70,80$, and $90 \%$ ethanol $\left(4{ }^{\circ} \mathrm{C}\right)$ and acetone $\left(25{ }^{\circ} \mathrm{C}\right)$ for 20 min in sequence, and finally embedded in resin before sectioning for the TEM observation.

\subsection{RNA extraction and microarray-chip analysis}

The total RNA was extracted and purified using the RNeasy Mini Kit (Qiagen, Hilden, Germany) and following the manufacturer's instructions. The RNA concentration was quantified with a Nanodrop ND-1000 spectrophotometer (Nanodrop Technologies, Wilmington, DE, USA) and the RNA integrity was assessed using standard denaturing agarose gel electrophoresis. Based on the physiological responses of the $N$. europaea cells after 40-d exposure to the $\mathrm{TiO}_{2} \mathrm{NPs}$, three triplicate samples, which included the pre-exposure cell sample (Pre.), the 12-d NP-impacted cell sample (Imp.), and the recovered cell sample after 40-d NP exposure (Rec.) were assayed using an oligonucleotide microarray (Agilent Technologies, Palo Alto, CA, USA) with all 2436 annotated transcripts represented in the $N$. europaea ATCC 19718 genome (Chain et al. 2003). The sample labeling and microarray hybridization were conducted following the Agilent One-Color Microarray-Based Gene Expression Analysis protocol (Agilent Technologies, Santa Clara, CA, USA). In brief, the total RNA from each sample was amplified and transcribed into fluorescent cRNA with Cy3-UTP labeled using Agilent's Quick Amp Labeling Kit (version 5.7, Agilent Technologies). The labeled cRNAs were then hybridized onto the $N$. europaea ATCC 19718 Microarray (8x15K, Agilent Technologies) using the Agilent Gene Expression Hybridization Kit. After washing, an Agilent Scanner G2505C (Agilent Technologies) was used to scan the arrays. 
11.0.1.1, Agilent Technologies) for the data analysis. The GeneSpring GX v12.0 software (Agilent

158 Technologies) was used for the quantile normalization of the data and subsequent processing. The regulation of the gene expressions was expressed as the fold-change ratio (FC) (log2 transformed) of the normalized signal intensity between the NP-impacted samples and the pre-exposure cells. of the genes' corresponding orthologous groups (COG) and the related pathway analysis were determined using the latest Microbial Genome Annotation and Analysis Platform (https://www.genoscope.cns.fr/agc/microscope/home/index.php) and the Kyoto Encyclopedia of Genes and Genomes database (http://www.genome.jp/kegg/kegg2.html). The microarray data has been submitted to the Gene Expression Omnibus database under accession number GSE111100 (https://www.ncbi.nlm.nih.gov/geo/query/acc.cgi?acc=GSE111100).

\section{6 qRT-PCR}

Three differentially expressed genes (NE0669, NE0731, and Rh50) were screened for the validation of the microarray results using a ViiA 7 Real-time PCR System (Applied Biosystems, USA). The extracted RNA for the microarray hybridization was also used in the qRT-PCR analysis. The specific primers were designed with Primer Premier 5.0 software (Premier Biosoft, Canada) and are listed in Table S1. The analysis procedures were explained in a previous study (Yu et al. 2016). The amplification conditions were: pre-denaturation at $95^{\circ} \mathrm{C}$ for $10 \mathrm{~min}$, denaturation at $95{ }^{\circ} \mathrm{C}$ for $10 \mathrm{~s}$, and annealing at $60{ }^{\circ} \mathrm{C}$ for $60 \mathrm{~s}$ (40 cycles). After application, the melting curve was obtained $\left(60-99^{\circ} \mathrm{C}\right.$, ramp rate: $\left.0.05^{\circ} \mathrm{C} / \mathrm{s}\right)$ to confirm the non-specific amplicons. Finally, the target gene expressions were normalized to that of the 16S rRNA genes. The 16S rRNA gene expressions were not significantly affected after $12-\mathrm{d}(\mathrm{p}=0.278)$ and $40-\mathrm{d}(\mathrm{p}=0.467) \mathrm{TiO}_{2} \mathrm{NP}$ exposure using t-test analysis.

\subsection{Statistical analysis}

Three replicate runs of two chemostats for 1 and $50 \mathrm{mg} / \mathrm{L}$ NP exposure were conducted. All the 
results are presented as means \pm standard deviation $(\mathrm{n}=3)$. Independent unpaired two-sample student's t-tests were used to assess significance and the statistical significance level was $\mathrm{p} \leq 0.05$.

\section{Results}

\subsection{NP characterization}

The average primary particle size of the ellipse-shaped $\mathrm{TiO}_{2}$ NPs as determined by SEM imaging was $42 \pm 11 \mathrm{~nm}$ (Fig. S1). The NPs' hydrodynamic size and $\zeta$ potential were $187 \pm 69 \mathrm{~nm}$ and $-20.4 \pm 2.1 \mathrm{mV}$, respectively.

\subsection{Physiological responses to chronic NP exposure}

3.2.1 Changes in cell density, average size, and $\zeta$ potential

One mg/L $\mathrm{TiO}_{2}$ NPs did not induce markedly negative effects on the cells' density (Fig. 1A), size $(884 \pm 42 \mathrm{~nm}$, Fig. S2A), and $\zeta$ potential $(-21.3 \pm 2.3 \mathrm{mV}$, Fig. S2B) during the entire 40-d exposure period. When exposed to $50 \mathrm{mg} / \mathrm{L} \mathrm{TiO}_{2} \mathrm{NPs}$, the cell density remained stable for the first 5 $\mathrm{d}$ and then significantly decreased $(\mathrm{p}=0.002)$ to as low as $48.6 \pm 7.8 \%$ of the original value at the end of the 10-d NP exposure (Fig. 1A). However, the cell density gradually approached the original value ( $\mathrm{p}=0.140$ ) after $30-\mathrm{d}$ incubation and finally remained (Fig. 1A). In contrast, the cell size significantly increased and the $\zeta$ potential decreased within the first $2 \mathrm{~d}$ but both reverted to the original levels although slight fluctuations were observed during the NP exposure period (Fig. S2).

3.2.2 Cell membrane integrity and morphology variations

The cell membrane integrities were first significantly compromised but then recovered from the $\mathrm{TiO}_{2}$ NP stress at the levels of 1 and $50 \mathrm{mg} / \mathrm{L}$ (Fig. 1B). During the $1 \mathrm{mg} / \mathrm{L} \mathrm{NP}$ exposure period, the cell membrane integrity gradually decreased but finally stabilized at $96.1 \%$. In contrast, at 50 $\mathrm{mg} / \mathrm{L} \mathrm{NP}$, the cell membrane integrity progressively recovered from the lowest value of $88.4 \pm 0.7 \%$ ( $\sim 12$ d) to around $96 \%$ at the end of the 30-d NP exposure period (Fig. 1B). The cell morphology changes were further examined using TEM imaging. The average lengths of the pre-exposure cells (Fig. 2A), the 12-d NP-impacted cells (Fig. 2B), and the 40-d NP-impacted cells (Fig. 2C) were 
$0.928 \pm 0.153,0.851 \pm 0.131$, and $0.859 \pm 0.141 \mu \mathrm{m}(\mathrm{n}=10)$ and the widths were $0.630 \pm 0.066$ $0.581 \pm 0.076$, and $0.590 \pm 0.103 \mu \mathrm{m}(\mathrm{n}=10)$, respectively. There were no significant differences in the lengths and widths between the treatments $(\mathrm{p} \leq 0.05)$ despite a slight decrease after the NP exposure. The pre-exposure cells without NP impact exhibited a clear and intact membrane structure (Fig. 2A). After 12-d exposure to $50 \mathrm{mg} / \mathrm{L} \mathrm{TiO}{ }_{2} \mathrm{NPs}$, the cell's multilayer membrane structure was strongly distorted and deformed or even became undistinguishable (Fig. 2B). This was consistent with the observed strongly impaired membrane integrity (Fig. 1B). However, after prolonged NP stress (40 d), the membrane integrity improvement of about $60-75 \%$ reflected the 
low DO level of $0.5 \mathrm{mg} / \mathrm{L}$ (Fig. 1 \& 3 ) despite the unremarkable changes in cell size and $\zeta$ potential (Fig. S2). In addition, the inhibition rates of all the metabolic activities of $N$. europaea were much higher in the low-DO cultured cells than in the cells cultured at $2 \mathrm{mg} \mathrm{DO} / \mathrm{L}$ after 6-h NP exposure (Fig. $1 \& 3$ ). However, the DO level did not affect the recovery potentials of the NP-impaired cells because the cells finally regained their metabolic activities and reached nearly the same levels as the normal cells despite the prolonged adaptation time for the low-DO cultured cells. Therefore, $N$. europaea cells displayed a DO-independent recoverability when long-term exposed to $\mathrm{TiO}_{2} \mathrm{NPs}$ and the high DO condition benefited the cells' resistance to NP stress and shortened the cells' NP toxicity adaptation and recovery time of the metabolic activity.

\subsection{Transcriptional profiling}

In comparison to the pre-exposure cells, 269 and 193 transcripts were differentially expressed with statistical significance $(\mathrm{p} \leq 0.05$, and $|\mathrm{FC}| \geq 1.0)$ in the NP-impaired and the recovered cells, respectively. The functional groups of the differentially regulated genes were generally categorized into the groups of cellular membrane metabolism or transport, information processing, amino acid or carbohydrate metabolism, energy production or conversion, cellular defense or repair, and secondary metabolisms (Fig. S3). Except for the unknown genes, the three most significantly expressed functional genes in the NP-impaired cells were related to amino acid metabolism, membrane biogenesis, and RNA translation or ribosomal metabolism. In addition, the number of differentially expressed genes in the clustered functional groups generally decreased after 40-d NP stress (Fig. S3). Overall, the transcriptional expression patterns of the NP-impaired cells after their 12-d and 40-d exposure to NPs were comparable and the NP toxicity impacts on the cells' transcriptional expressions were generally alleviated by the extension of the NP exposure time.

\subsubsection{Amino acid and RNA translation or ribosomal metabolisms}

Nineteen of the 22 amino acid metabolism-related genes encoding transferase, synthase, reductase, isomerase, and kinase were significantly up-regulated after 12-d NP stress, whereas only 3 genes encoding methionine and arginine metabolism were down-regulated (Fig. 4A). However, 
the over-expression levels of these genes were generally alleviated after 40-d incubation and 18 of the 22 affected genes reverted back to their original expression levels. These results strongly suggested that the regulations of amino acid metabolism at the transcriptional level actively participated in the cellular adaption and recovery processes under $\mathrm{TiO}_{2} \mathrm{NP}$ stress.

Nineteen transcripts encoding RNA translation or ribosomal metabolism were dramatically up-regulated after 12-d and 40-d NP impacts (Fig. 4B). With prolonged NP impact, 13 of the 19 up-regulated genes reverted back to the original levels. In contrast, 12 transcripts encoding RNA helicase, methyltransferase, and 16/30S ribosomal protein were over-expressed only after 40-d NP exposure. Overall, the self-regulations of the aminoacyl-tRNA biosynthesis, RNA translation, and the ribosomal metabolism pathways in the $\mathrm{TiO}_{2}$ NP-impaired cells were probably significantly activated to resist the NP stress.

\subsubsection{Membrane transport and associated metabolisms}

The NPs interrupted the expression of the membrane transport and biogenesis-related genes encoding inorganic ion transporters, membrane efflux, membrane fusion, and peptidoglycan biosynthesis (Fig. 5). After 12-d NP exposure, 19 genes mainly encoding transmembrane binding, receptor, fusion, or efflux proteins for general substrate transport and acriflavin resistance were significantly up-regulated ( $\mathrm{p} \leq 0.05, \mathrm{FC} \geq 1$ ). The 18 genes that were significantly down-regulated ( $\mathrm{p} \leq 0.05, \mathrm{FC} \leq-1)$ were mainly related to sulfate, copper, or ammonium transport and glycometabolism. However, 22 of these up/down-regulated transcripts were able to return to their original expression levels after 40-d incubation, which indicated the possible membrane repair regulations. In addition, transcripts encoding acriflavin resistance, major facilitator transport, or pore ion channels were further up-regulated and 6 transcripts encoding peptidoglycan biosynthesis were down-regulated after 40-d NP exposure. Therefore, the membrane metabolism associated regulations were actively involved in cellular adaption/recovery during the chronic NP exposure.

\subsubsection{Energy metabolisms}

Thirteen and 5 transcripts for energy production/conversion were statistically differentially 
expressed ( $\mathrm{p} \leq 0.05,|\mathrm{FC}|>1$ ) after $12-\mathrm{d}$ and $40-\mathrm{d}$ NP stress, respectively (Fig. 6). Among them, 4 genes involved with the respiratory chain or electron transport and ATP production were related to NADH-quinone reduction and the tricarboxylic acid (TCA) cycle. After 40-d incubation, the expressions of up-regulated genes were significantly lessened except for one ATP-citrate lyase-encoding gene and all the significantly down-regulated transcripts regained their original expression levels. Therefore, the energy production/conversions pathways were probably impacted by the $\mathrm{TiO}_{2}$ NPs and the associated regulations of the respiration chain and ATP production were assumed to be actively involved in the cellular adaption and recovery processes.

\subsection{Verification of microarray results}

Three representative genes at different expression levels were subjected to qRT-PCR for verification of the microarray results. The gene NE0669 encoding the acriflavin resistance protein for stress resistance was highly up-regulated with an FC of 4.30 and 4.99 after 12-d and 40-d NP stress, respectively (Table 1). The gene Rh50 encoding ammonium transporters and the gene NE0371 encoding the TonB-dependent receptor protein were both significantly differentially expressed (Table 1). Generally, their expressions as quantified by the qRT-PCR displayed similar varying trends as the microarray results although a smaller FC ratio was obtained with the qRT-PCR.

\section{Discussion}

\subsection{Cell responses and adaptions to long-term $\mathrm{TiO}_{2} \mathrm{NP}$ exposure}

N. europaea displayed a strong adaptation potential during the long-term exposure to $\mathrm{TiO}_{2} \mathrm{NPs}$ in a continuous cultivation reactor and the compromised cell density, membrane integrity, nitritation performance, and AMO activity gradually recovered (Fig. 1-3). The nitritation performances of AOB were observed to recover from $0.1 \mathrm{mg} / \mathrm{L} \mathrm{Ag} \mathrm{NPs} \mathrm{stress} \mathrm{in} \mathrm{a} \mathrm{nitrifying} \mathrm{SBR} \mathrm{(Alito} \mathrm{and} \mathrm{Gunsch}$ 2014) and 150-d ZnO NP exposure in a completely autotrophic nitrogen removal over nitrite 
(CANON) system (Zhang et al. 2017). These results reflect the possible anti-toxicity and adaptation

capacities of AOB under NP stress. It was assumed that the diversity of the microbial community and the survival of insensitive bacteria contributed to the recovery of the BNR performances as a result of a selection process under Ag NP (Alito and Gunsch 2014) and ZnO NP stress (Zhang et al. 2017). Considering the different sensitivity of $N$. europaea cells during their $8-12 \mathrm{~h}$ generation time (Skinner and Walker 1961), the cell density first decreased and then recovered (Fig. 1A); this may be attributable to the sensitive cells' decay and the continuous cell proliferation. However, the membrane integrity improvement (Fig. 1B) and structure distortion alleviation (Fig. 2) indicated that the response of $N$. europaea to the $\mathrm{TiO}_{2} \mathrm{NPs}$ might not only be attributed to selection but may also be an 'inhibition-recovery' process. The $50 \mathrm{mg} / \mathrm{L} \mathrm{ZnO} \mathrm{NP-impacted} \mathrm{continuously} \mathrm{grown} N$. europaea cells have been reported to revert to their metabolic performances after the release of 6-h $\mathrm{NP}$ stress although the prolonging of the $\mathrm{ZnO} \mathrm{NP}$ impacts finally caused irreversible cell impairment ( $\mathrm{Wu}$ et al. 2017). $\mathrm{TiO}_{2}$ NPs are generally photosensitive and cause photooxidative damage to cells (Miller et al. 2012). In this study, the cells were exposed to $\mathrm{TiO}_{2} \mathrm{NPs}$ in the dark and the NPs' non-photooxidative stress and physical 'stab' (Liu et al. 2009) probably contributed to the main nanotoxicity effects. ZnO NPs with high solubility are well known to cause more toxic impacts than $\mathrm{TiO}_{2}$ NPs (Yu et al. 2015). Therefore, the impaired cells were expected to display greater adaption or recovery potentials under less toxic $\mathrm{TiO}_{2}$ stress than $\mathrm{ZnO}$ NPs.

\subsection{RNA translation or ribosomal metabolism regulations}

The stimulation of RNA translation or ribosomal metabolism pathways, such as aminoacyl-tRNA biosynthesis and RNA or ribosome modifications, are probably involved in mediating functional protein or enzyme synthesis as cellular anti-toxicity and self-adaption behaviors. It is well known that aminoacyl-tRNA synthetase catalyzes the primary step of the protein biosynthesis via attaching amino acids to the associated tRNAs (Schimmel and Söll 1979). Aminoacyl-tRNA synthetases including glycine, arginine, and leucine were demonstrated to be positively correlated with the Escherichia coli growth rate (Neidhardt et al. 1977). The observed 
up-regulation of aminoacyl-tRNA $($ gatAB $)$ and the associated amino acid $(g c v T H 1, \arg C$, and $\operatorname{leuA})$ biosynthesis encoding genes in response to the $12-\mathrm{d} \mathrm{TiO}_{2} \mathrm{NP}$ stress (Fig. 4) probably promoted the cell growth to regain the original cell density (Fig. 1A). The up-regulations of gatAB and the amino acid encoding genes $\arg B$ and his $D$ for energy conservation were reported to resist $1 \mu \mathrm{M}$ cadmium associated amino acid biosynthesis pathways were stimulated for cellular resistance and adaption to the $\mathrm{TiO}_{2} \mathrm{NP}$ stress. Ribosomes are considered the main sites for cellular protein biosynthesis (Ramakrishnan 2002). The increased expressions of the ribosomal protein biogenesis encoding operators, such as $r p s D E, r p m F$, and $r p l Q$ were detected in the $N$. europaea cells in response to zinc, linear alkylbenzene sulfonates, or ZnO NPs stress to resist toxicity effects (Wu et al. 2017; Urakawa et al. 2008; Park and Ely 2008b). Thus, the observed up-regulation of the ribosome biosynthesis (rpsBU) or the modification factor (truB, $k s g A)$ encoding genes (Fig. 4) might contribute to the recovery of the impaired protein or enzyme functions and the improvement in the metabolic activities. Overall, the stimulations of the RNA translation or ribosomal metabolism regulations promoted the resistance and recovery process of $N$. europaea to the $\mathrm{TiO}_{2} \mathrm{NP}$ stress.

\subsection{Membrane metabolism regulations}

Membrane repair involved transport and the associated metabolism regulation processes are crucial for the cells' adaption to the $\mathrm{TiO}_{2}$ NP stress. Fang et al. (2007) reported on the variations of the membrane lipid components and membrane fluidity in denitrification-associated Bacillus subtilis to resist fullerene NP stress. In our study, the NP-impaired membrane integrity gradually increased with the increase in the NP exposure time (Fig. 1B), which suggested the possible membrane repair processes. Our microarray results further revealed the varied expressions of numerous transcripts encoding the membrane transport, efflux system, and structure preservation during the chronic $\mathrm{TiO}_{2}$ NP stress (Fig. 5). For example, the expressions of acriflavin resistance (NE0669), the membrane efflux/fusion protein (NE0373, NE0668, NE0670), and the major facilitator transporter (MFC) (NE2454) genes were up-regulated. These genes are associated with 
efflux pumps (EP) (Chain et al. 2003) for drug-resistance or environmental stress-resistance regulations (Amaral et al. 2011), which are generally performed by a combination of an inner efflux protein and a membrane-embedded fusion protein (Ma et al. 1994). The up-regulation of the EP-associated genes might be a survival or adaption effort of the NP-impaired cells trying to capture the potential 'invaders' and transport them outside the membrane for toxin exclusion and stress alleviation. The EP-associated genes were also found to be overexpressed due to stress resistance or alleviation in response to heavy metals (Park and Ely 2008a) and ZnO NP (Wu et al. 2017) stress. In addition, magnesium is essential for cell growth as a cofactor during ATP-requiring enzymatic catalysis and plays a critical role in transmembrane electrolyte flux adjustment via binding the active site or causing a conformational change of the enzyme (Ryan 1991). An increase in the magnesium concentration from 270 to $2,250 \mu \mathrm{M}$ was reported to promote the nitrifying activity of $N$. europaea under $\mathrm{Zn}^{2+}$ stress (Radniecki et al. 2009). Therefore, the observed up-regulation of the magnesium transporter-associated gene (NE0373) indicated cellular self-protection/recovery behavior to help recover the impaired membrane permeability and nitrifying activities under NP stress. Furthermore, potassium is known as an osmotic solute to activate enzymes or transport systems for cellular osmotic-regulation (Epstein 2003). The transmembrane potential is mainly determined by the transmembrane potassium gradient (Corratgé-Faillie et al. 2010). The NP damaged cell membrane integrity (Fig. 1B) and structure (Fig. 2B) might lead to a potassium leakage outside the membrane, thus disrupting the transmembrane potential and osmotic balance. The observed up-regulation of the potassium transporter-encoding gene (trkA) suggested that the cells' active potassium transport processes probably prevent an inner potassium deficiency and maintain the transmembrane osmotic balance to resists the $\mathrm{TiO}_{2} \mathrm{NP}$ stress.

At the end of the 40-d NP stress, the regulated transcript expressions encoding the membrane-related metabolisms were generally alleviated (Fig. 5), which indicated the cell's physiological performance recovery potentials (Fig. 1-3). For instance, the inhibited expressions of the genes encoding the sulfate $(c y s A W)$ and ammonium transport $(R h 50)$ recovered and returned 
back to their original levels after $12-\mathrm{d} \mathrm{TiO}_{2}$ stress. The decreased expressions of the cyanophycin synthetase encoding genes (NE0922/0923) for substrate reservation (Hai et al. 2006) significantly recovered during the chronic $\mathrm{TiO}_{2} \mathrm{NP}$ stress. It is noteworthy that the expression of the genes encoding the peptidoglycan biosynthesis (Fig. 5), an important membrane constituent for skeleton structure preservation (Vollmer et al. 2008, Vollmer and Höltje 2004) were continuously depressed in accordance with the impaired cell membrane structure (Fig. 2C); this was probably due to the persistent NP-cell contact that compromised the cell membrane mending effects. In summary, the interruptions of the membrane structure and the associated functions represented the important toxicity mechanisms of the $\mathrm{TiO}_{2}$ NPs and the regulations of the corresponding membrane-related metabolic processes were crucial for the cells' self-adaption and recovery processes.

\subsection{Energy metabolism regulations}

The regulations of the energy metabolisms, such as the respiratory electron transfer chain and the TCA cycle pathways contributed to the cells' adaption to the $\mathrm{TiO}_{2} \mathrm{NP}$ stress. After 12-d exposure to the NPs, the cytochrome c oxidase (SCO1, NE0926) and ATP production (atpB) encoding transcripts (Fig. 6) were stimulated although the NADH-ubiquinone oxidoreductase encoding genes $(n q r B C D)$ for NADH consumption (EC 1.6.5.8) were down-regulated. The cells probably recovered the energy production efficiency by promoting the electron transfer and ATP production via stimulation of the proton gradient generation in the electron transfer chain (Chain et al. 2003). In addition, the significantly inhibited energy-associated gene expressions generally reverted back to their original level $(|\mathrm{FC}|<1)$ with the increase in the cell incubation time under the NP stress, especially for the TCA cycle-related encoding transcripts $(s u c B, s d h A D)$ responsible for the recovery of respiration and the TCA cycle-related energy metabolisms. Moreover, the continuous up-regulations of the genes $\operatorname{cox} B A 2$ related to the oxygen-dependent proton gradient generations (Keilin and Hartree 1938) and $a t p B$ involved in ATP production (Kumar and Nicholas 1982) might further enhance the energy production efficiency during the prolonged NP exposure period; this behavior has been observed in $N$. europaea cells after 6-h exposure to $50 \mathrm{mg} / \mathrm{L} \mathrm{ZnO}$ 
NPs as a self-resistance response (Wu et al. 2017). Overall, the energy metabolism pathways including the respiratory electron transfer and the TCA cycle were impacted by the $\mathrm{TiO}_{2} \mathrm{NPs}$ and the stimulations of the oxygen-dependent electron transfer and the proton-dependent ATP production were assumed to increase the cellular energy production/conversion for cell adaption to the $\mathrm{TiO}_{2} \mathrm{NP}$ chronic stress.

\subsection{Toxin-antitoxin, non-photooxidative stress responses and DNA repair}

The toxin-antitoxin (TA) system is generally considered to be involved in the prokaryotic defense and stress-related adaptation (Van Melderen 2010). Two type II TA genes (NE1563, NE1583) and one TA system-related gene (mreB) were up-regulated after 12-d and 40-d NP stress, respectively (Table 2). The over-expressions of the TA genes might contribute to the cellular adaption to the $\mathrm{TiO}_{2}$ NP stress and this may occur via genomic fragment stabilization and DNA protection (Wozniak and Waldor 2009). The up-regulation of the DNA repair and replication encoding genes (e.g. $r d g C$ and $s s b$, Table 2) further supported the cells' TA adaption mechanism. Some studies have reported the regulation of TA genes in $N$. europaea cells when threatened by chloroform and $\mathrm{ZnO}$ NPs (Wu et al. 2017, Gvakharia et al. 2007). In addition, the up-regulation of the oxidative stress response-related genes were also detected even in the dark (Table 2). $\mathrm{TiO}_{2}$ has been demonstrated to induce ROS generation and exert oxidative damage on biofilm microbes (Battin et al. 2009) and human cells (Sayes et al. 2006) in the absence of light. The extracytoplasmic function (ECF) sigma factor is considered to be involved in 'stress-fighting' as an oxidative stress response (Chain et al. 2003). Thioredoxin with reducing ability is also widely recognized as a detoxicant for oxidative stress alleviation under NP stress (Yang et al. 2012). The observed up-regulation of these stress-defense related genes indicated their contributions to cellular adaptions under chronic $\mathrm{TiO}_{2} \mathrm{NP}$ stress.

\subsection{DO impact on cellular adaption}

The cells cultured under either 0.5 or $2.0 \mathrm{mg} / \mathrm{L}$ DO conditions regained the previously decreased cell density, membrane integrity, nitritation performance, and AMO activity at the end of 
the 40-d incubation with $\mathrm{TiO}_{2}$ NPs. Nevertheless, the low-DO cultivated cells were more susceptible to the $\mathrm{TiO}_{2}$ NPs stress and required more time for adaption (Fig. $1 \& 3$ ). N. europaea cells are well known to obtain energy from ammonia oxidation by using only two of four produced electrons from hydroxylamine oxidation for ATP production (Prosser 1990), which results in a low net gain in terms of energy production/conversion. When the oxygen supply was low, the proton-driven force generated by the oxygen reduction for the ATP production was inefficient, which might cause the severe limitation of the energy conversion and the associated substance metabolism, such as the carbon fixation, the TCA cycle, the amino acid metabolism, and the membrane metabolism (Chain et al. 2003). In addition, the electron transfer chain originating from the $\mathrm{NH}_{2} \mathrm{OH}$ oxidation might be stimulated to enhance the energy production efficiency for stress resistance and adaption because the cytochrome c oxidase encoding genes were significantly up-regulated after NP exposure (Fig. 6), whereas the cycled electron transfer chain back to the AMO catalyzation was inhibited (Fig. S4), which resulted in the inhibition of the AMO activity (Fig. 3C). Whittaker et al. (2000) have also reported similar energy regulation and AMO inhibition mechanisms under protonophore chlorocarbonylcyanidephenyl hydrazone (CCCP) stress. Therefore, under lower DO levels, the stimulation of energy production by oxygen reduction for cell resistance/adaption might be insufficient, which might cause more severe AMO limitations (Fig. $3 \mathrm{C})$. Furthermore, the up-regulation of the gene $\operatorname{cox} B A 2$ encoding cytochrome oxidase aa 3 for the oxygen-dependent proton gradient generation (Keilin and Hartree 1938) and the stimulation of the ATP production were responsible for the cellular adaptions as discussed above, which might be potentially depressed under low DO conditions (Fig. S4). Overall, an insufficient oxygen supply might exert negative effects on the stimulation of energy production/conversion and the regulations of the related metabolisms and finally result in lower cell adaption potentials at low DO conditions.

\section{Conclusion}

The novelty of this study was a comprehensive exploration of the adaption and recovery of an 
ammonia oxidizer, $N$. europaea, under chronic $\mathrm{TiO}_{2}$ NP stress and different DO conditions at the physiological, metabolic, and transcriptional levels. A deep understanding of the self-adaptive regulations or self-recovery potentials of NP-impaired AOB is essential and crucial for developing emergency adjustment strategies in response to NP contamination in the BNR process. The main findings of this study are:

- The impaired cell density, membrane integrity, nitritation performance, and specific AMO activity recovered after exposure to $50 \mathrm{mg} / \mathrm{L} \mathrm{TiO}_{2} \mathrm{NP}$ long-term stress.

- Low DO cultivated cells were more susceptible to chronic NP stress and displayed less efficient adaption capacities; this was probably due to the limitation of the oxygen-dependent energy production/conversion with a deficient oxygen supply.

- The interruption of the membrane structure and the associated functions were the direct consequences of the biotoxicity of the $\mathrm{TiO}_{2}$ NPs. The corresponding regulations of the membrane-associated metabolic processes were crucial for the cellular self-adaption and recovery processes, such as the membrane efflux for toxicants exclusion, maintenance of the structural stability, membrane osmotic adjustment, and substrate transport regulation.

- The stimulations of the RNA translation or ribosomal metabolisms including the aminoacyl-tRNA biosynthesis and RNA /ribosome modification pathways were actively involved in cell growth promotion and cellular adaptions to the NP stress.

- The regulations of the energy metabolisms, especially the TCA cycle, the electron transfer, and the ATP biosynthesis pathways enhanced the energy production efficiency for cell recovery.

- TA 'stress fighting', non-photooxidative stress quenching, and DNA repair processes were also actively involved in the cellular adaption and recovery during the long-term exposure to the $\mathrm{TiO}_{2}$ NPs stress.

\section{Acknowledgment}


This work was supported by National Natural Science Foundation of China (51678134 and 51208092), Natural Science Foundation of Jiangsu Province, China (SBK2017020636), Innovative Graduate Student Project of Jiangsu Province (KYLX16_0282), and Scientific Research Foundation of Graduate School of Southeast University. The authors thank Alejandro Palomo from Technical University of Denmark for the helpful comments on the manuscript.

\section{References}

Alito, C.L. and Gunsch, C.K. (2014) Assessing the effects of silver nanoparticles on biological nutrient removal in bench-scale activated sludge sequencing batch reactors. Environmental Science and Technology 48(2), 970-976.

Amaral, L., Fanning, S. and Pagès, J.-M. (2011) Advances in Enzymology and Related Areas of Molecular Biology. Toone, E.J. (ed).

Battin, T.J., Kammer, F.v.d., Weilhartner, A., Ottofuelling, S. and Hofmann, T. (2009) Nanostructured $\mathrm{TiO}_{2}$ : Transport behavior and effects on aquatic microbial communities under environmental conditions. Environmental Science and Technology 43(21), 8098-8104.

Binh, C.T.T., Adams, E., Vigen, E., Tong, T., Alsina, M.A., Gaillard, J.-F., Gray, K.A., Peterson, C.G. and Kelly, J.J. (2016) Chronic addition of a common engineered nanomaterial alters biomass, activity and composition of stream biofilm communities. Environmental Science: Nano 3(3), 619-630.

Chain, P., Lamerdin, J., Larimer, F., Regala, W., Lao, V., Land, M., Hauser, L., Hooper, A., Klotz, M., Norton, J., Sayavedra-Soto, L., Arciero, D., Hommes, N., Whittaker, M. and Arp, D. (2003) Complete genome sequence of the ammonia-oxidizing bacterium and obligate chemolithoautotroph Nitrosomonas europaea. Journal of Bacteriology 185(9), 2759-2773.

Corratgé-Faillie, C., Jabnoune, M., Zimmermann, S., Véry, A.-A., Fizames, C. and Sentenac, H. (2010) Potassium and sodium transport in non-animal cells: the Trk/Ktr/HKT transporter 

family. Cellular and Molecular Life Sciences 67(15), 2511-2532.

Epstein, W. (2003) The roles and regulation of potassium in bacteria. Progress in Nucleic Acid Research and Molecular Biology 75, 293-320.

Fang, J.S., Lyon, D.Y., Wiesner, M.R., Dong, J.P. and Alvarez, P.J.J. (2007) Effect of a fullerene water suspension on bacterial phospholipids and membrane phase behavior. Environmental Science and Technology 41(7), 2636-2642.

Gondikas, A.P., Von Der Kammer, F., Reed, R.B., Wagner, S., Ranville, J.F. and Hofmann, T. (2014) Release of $\mathrm{TiO}_{2}$ nanoparticles from sunscreens into surface waters: a one-year survey at the Old Danube recreational lake. Environmental Science and Technology 48(10), 54155422.

Gottschalk, F., Sonderer, T., Scholz, R.W. and Nowack, B. (2009) Modeled environmental concentrations of engineered nanomaterials $\left(\mathrm{TiO}_{2}, \mathrm{ZnO}, \mathrm{Ag}, \mathrm{CNT}\right.$, Fullerenes) for different regions. Environmental Science and Technology 43(24), 9216-9222.

Gvakharia, B., Permina, E., Gelfand, M., Bottomley, P., Sayavedra-Soto, L. and Arp, D. (2007) Global transcriptional response of Nitrosomonas europaea to chloroform and chloromethane. Applied and Environmental Microbiology 73(10), 3440-3445.

Hai, T., Frey, K.M. and Steinbuchel, A. (2006) Engineered cyanophycin synthetase (CphA) from Nostoc ellipsosporum confers enhanced $C p h A$ activity and cyanophycin accumulation to Escherichia coli. Applied and Environmental Microbiology 72(12), 7652-7660.

Hu, Q., Guo, F., Zhao, F. and Fu, Z. (2017) Effects of titanium dioxide nanoparticles exposure on parkinsonism in zebrafish larvae and PC12. Chemosphere 173, 373-379.

Huang, G., Ng, T.W., An, T., Li, G., Wang, B., Wu, D., Yip, H.Y., Zhao, H. and Wong, P.K. (2017) Interaction between bacterial cell membranes and nano- $\mathrm{TiO}_{2}$ revealed by two-dimensional FTIR correlation spectroscopy using bacterial ghost as a model cell envelope. Water Research 118, 104-113.

Keilin, D. and Hartree, E.F. (1938) Cytochrome $a$ and cytochrome oxidase. Nature 141, 870-871. 
Kowalchuk, G.A. and Stephen, J.R. (2001) Ammonia-oxidizing bacteria: a model for molecular microbial ecology. Annual Review of Microbiology 55, 485-529.

Kumar, S. and Nicholas, D.J.D. (1982) A protonmotive force-dependent adenosine-5 ' triphosphate synthesis in spheroplasts of Nitrosomonas europaea. FEMS Microbiology Letters 14, 21-25.

Li, B., Huang, W., Zhang, C., Feng, S., Zhang, Z., Lei, Z. and Sugiura, N. (2015) Effect of TiO nanoparticles on aerobic granulation of algal-bacterial symbiosis system and nutrients removal from synthetic wastewater. Bioresource Technology 187, 214-220.

Li, D., Li, B., Wang, Q., Hou, N., Li, C. and Cheng, X. (2016) Toxicity of $\mathrm{TiO}_{2}$ nanoparticle to denitrifying strain CFY1 and the impact on microbial community structures in activated sludge. Chemosphere 144, 1334-1341.

Li, Y., Zhang, W., Niu, J.F. and Chen, Y.S. (2012) Mechanism of photogenerated reactive oxygen species and correlation with the antibacterial properties of engineered metal-oxide nanoparticles. ACS Nano 6(6), 5164-5173.

Li, Z., Wang, X., Ma, B., Wang, S., Zheng, D., She, Z., Guo, L., Zhao, Y., Xu, Q., Jin, C., Li, S. and Gao, M. (2017) Long-term impacts of titanium dioxide nanoparticles $\left(\mathrm{TiO}_{2} \mathrm{NPs}\right)$ on performance and microbial community of activated sludge. Bioresource Technology 238, 361-368.

Liu, S.B., Wei, L., Hao, L., Fang, N., Chang, M.W., Xu, R., Yang, Y.H. and Chen, Y. (2009) Sharper and faster "Nano Darts" kill more bacteria: A study of antibacterial activity of individually dispersed pristine single-walled carbon nanotube. ACS Nano 3(12), 3891-3902.

Liu, W., Bertrand, M., Chaneac, C. and Achouak, W. (2016) $\mathrm{TiO}_{2}$ nanoparticles alter iron homeostasis in Pseudomonas brassicacearum as revealed by PrrF sRNA modulation. Environmental Science Nano 3, 1473-1482.

Ma, D., Cook, D.N., Hearst, J.E. and Nikaido, H. (1994) Efflux pumps and drug resistance in gram-negative bacteria. Trends in Microbiology 2(12), 489-493. 
Miller, R.J., Bennett, S., Keller, A.A., Pease, S. and Lenihan, H.S. (2012) $\mathrm{TiO}_{2}$ nanoparticles are phototoxic to marine phytoplankton. PloS One 7(1), e30321.

Minetto, D., Libralato, G. and Volpi Ghirardini, A. (2014) Ecotoxicity of engineered $\mathrm{TiO}_{2}$ nanoparticles to saltwater organisms: An overview. Environment International 66, 18-27.

Neidhardt, F.C., Bloch, P.L., Pedersen, S. and Reeh, S. (1977) Chemical measurement of steady-state levels of ten aminoacyl-transfer ribonucleic acid synthetases in Escherichia coli. Journal of Bacteriology 129(1), 378-387.

Park, S. and Ely, R.L. (2008a) Candidate stress genes of Nitrosomonas europaea for monitoring inhibition of nitrification by heavy metals. Applied and Environmental Microbiology 74(17), 5475-5482.

Park, S. and Ely, R.L. (2008b) Genome-wide transcriptional responses of Nitrosomonas europaea to zinc. Archives of Microbiology 189(6), 541-548.

Piccinno, F., Gottschalk, F., Seeger, S. and Nowack, B. (2012) Industrial production quantities and uses of ten engineered nanomaterials in Europe and the world. Journal of Nanoparticle Research 14(9), 1109.

Polesel, F., Farkas, J., Kjos, M., Almeida Carvalho, P., Flores-Alsina, X., Gernaey, K.V., Hansen, S.F., Plósz, B.G. and Booth, A.M. (2018) Occurrence, characterisation and fate of (nano)particulate $\mathrm{Ti}$ and $\mathrm{Ag}$ in two Norwegian wastewater treatment plants. Water Research $141,19-31$.

Prosser, J.I. (1990) Autotrophic nitrification in bacteria. Advances in Microbial Physiology 30, 125-181.

Radniecki, T.S., Semprini, L. and Dolan, M.E. (2009) Expression of merA, amoA and hao in continuously cultured Nitrosomonas europaea cells exposed to zinc chloride additions. Biotechnology and Bioengineering 102(2), 546-553.

Ramakrishnan, V. (2002) Ribosome structure and the mechanism of translation. Cell 108(4), $557-572$. 
Robichaud, C.O., Uyar, A.E., Darby, M.R., Zucker, L.G. and Wiesner, M.R. (2009) Estimates of upper bounds and trends in nano- $\mathrm{TiO}_{2}$ production as a basis for exposure assessment. Environmental Science and Technology 43(12), 4227-4233.

Ryan, M.F. (1991) The role of magnesium in clinical biochemistry: An overview. Annals of Clinical Biochemistry 28(1), 19-26.

Schimmel, P.R. and Söll, D. (1979) Aminoacyl-tRNA synthetases: general features and recognition of transfer RNAs. Annual Review of Biochemistry 48, 601-648.

Sayes, C.M., Wahi, R., Kurian, P.A., Liu, Y., West, J.L., Ausman, K.D., Warheit, D.B. and Colvin, V.L. (2006) Correlating nanoscale titania structure with toxicity: A cytotoxicity and inflammatory response study with human dermal fibroblasts and human lung epithelial cells. Toxicological Sciences 92(1), 174-185.

SEPAC (2002) Methods for monitor and analysis of water and wastewater China Environment Science Press (in Chinese), Beijing.

Skinner, F.A. and Walker, N. (1961) Growth of Nitrosomonas europaea in batch and continuous culture. Archives of Microbiology 38(4), 339-349.

Sun, T.Y., Gottschalk, F., Hungerbuhler, K. and Nowack, B. (2014) Comprehensive probabilistic modelling of environmental emissions of engineered nanomaterials. Environmental Pollution 185, 69-76.

Urakawa, H., Matsumoto, J., Inaba, K. and Tsuneda, S. (2008) DNA microarray mediated transcriptional profiling of Nitrosomonas europaea in response to linear alkylbenzene sulfonates. FEMS Microbiology Letters 282(2), 166-173.

Van Melderen, L. (2010) Toxin-antitoxin systems: why so many, what for? Current Opinion in Microbiology 13(6), 781-785.

Vance, M.E., Kuiken, T., Vejerano, E.P., Mcginnis, S.P., Jr, H.M., Rejeski, D. and Hull, M.S. (2015) Nanotechnology in the real world: Redeveloping the nanomaterial consumer products inventory. Beilstein Journal of Nanotechnology 6, 1769-1780. 
Vollmer, W., Blanot, D. and De Pedro, M. (2008) Peptidoglycan structure and architecture. FEMS Microbiology Reviews 32(2), 149-167.

Vollmer, W. and Höltje, J.-V. (2004) The architecture of the murein (peptidoglycan) in gram-negative bacteria: Vertical scaffold or horizontal layer(s)? Journal of Bacteriology 186(18), 5978-5987.

Westerhoff, P., Song, G.X., Hristovski, K. and Kiser, M.A. (2011) Occurrence and removal of titanium at full scale wastewater treatment plants: implications for $\mathrm{TiO}_{2}$ nanomaterials. Journal of Environmental Monitoring 13(5), 1195-1203.

Whittaker, M., Bergmann, D., Arciero, D. and Hooper, A.B. (2000) Electron transfer during the oxidation of ammonia by the chemolithotrophic bacterium Nitrosomonas europaea. Biochimica et Biophysica Acta 1459(2-3), 346-355.

Wozniak, R.A.F. and Waldor, M.K. (2009) A toxin-antitoxin system promotes the maintenance of an integrative conjugative element. PLoS Genetics 5(3), e1000439.

Wu, J., Lu, H., Zhu, G., Chen, L., Chang, Y. and Yu, R. (2017) Regulation of membrane fixation and energy production/conversion for adaptation and recovery of $\mathrm{ZnO}$ nanoparticle impacted Nitrosomonas europaea. Applied Microbiology and Biotechnology 101(7), 2953-2965.

Yang, Y., Wang, J., Xiu, Z. and Alvarez P.J. (2013) Impacts of silver nanoparticles on cellular and transcriptional activity of nitrogen $\square$ cycling bacteria. Environmental Toxicology and Chemistry 32(7), 1488-1494.

Yang, Y., Wang, J., Zhu, H., Colvin, V.L. and Alvarez, P.J. (2012) Relative susceptibility and transcriptional response of nitrogen cycling bacteria to quantum dots. Environmental Science and Technology 46(6), 3433-3441.

Yu, Q., Wang, H., Peng, Q., Li, Y., Liu, Z. and Li, M. (2017) Different toxicity of anatase and rutile $\mathrm{TiO}_{2}$ nanoparticles on macrophages: Involvement of difference in affinity to proteins and phospholipids. Journal of Hazardous Materials 335, 125-134. 
Yu, R., Fang, X., Somasundaran, P. and Chandran, K. (2015) Short-term effects of $\mathrm{TiO}_{2}, \mathrm{CeO}_{2}$, and $\mathrm{ZnO}$ nanoparticles on metabolic activities and gene expression of Nitrosomonas europaea. Chemosphere 128, 207-215.

Yu, R., Wu, J., Liu, M., Zhu, G., Chen, L., Chang, Y. and Lu, H. (2016) Toxicity of binary mixtures of metal oxide nanoparticles to Nitrosomonas europaea. Chemosphere 153, 187-197.

Zahra, Z., Waseem, N., Zahra, R., Lee, H., Badshah, M.A., Mehmood, A., Choi, H.-K. and Arshad, M. (2017) Growth and metabolic responses of rice (Oryza sativa L.) cultivated in phosphorus deficient soil amended with $\mathrm{TiO}_{2}$ nanoparticles. Journal of Agricultural and Food Chemistry 65(28), 5598-5606.

Zhang, X., Zhang, N., Fu, H., Chen, T., Liu, S., Zheng, S. and Zhang, J. (2017) Effect of zinc oxide nanoparticles on nitrogen removal, microbial activity and microbial community of CANON process in a membrane bioreactor. Bioresource Technology 243, 93-99.

Zhang, X., Zhou, Y., Xu, T., Zheng, K., Zhang, R., Peng, Z. and Zhang, H. (2018) Toxic effects of $\mathrm{CuO}, \mathrm{ZnO}$ and $\mathrm{TiO}_{2}$ nanoparticles in environmental concentration on the nitrogen removal, microbial activity and community of anammox process. Chemical Engineering Journal 332, $42-48$.

Zheng, X., Chen, Y. and Wu, R. (2011a) Long-term effects of titanium dioxide nanoparticles on nitrogen and phosphorus removal from wastewater and bacterial community shift in activated sludge. Environmental Science and Technology 45(17), 7284-7290.

Zheng, X.O., Wu, R. and Chen, Y.G. (2011b) Effects of $\mathrm{ZnO}$ nanoparticles on wastewater biological nitrogen and phosphorus removal. Environmental Science and Technology 45(7), 2826-2832.

Zhou, X.H., Huang, B.C., Zhou, T., Liu, Y.C. and Shi, H.C. (2015) Aggregation behavior of engineered nanoparticles and their impact on activated sludge in wastewater treatment. Chemosphere 119, 568-576. 
Fig. 1 Changes in the cell concentration (A) and membrane integrity (B) under different DO conditions during chronic $\mathrm{TiO}_{2} \mathrm{NP}$ exposure

Fig. 2 TEM images of normal cells (A), 12-d (B), and 40-d (C) $\mathrm{TiO}_{2}$ NP-impaired cells with a DO concentration of $2.0 \mathrm{mg} / \mathrm{L}$. The red arrows indicate the distortion of the membrane and the yellow arrows indicate the undistinguishable membrane structure.

Fig. 3 Changes in the ammonium (A) and nitrite (B) concentrations and the specific AMO activities (C) in the chemostat reactor at different $\mathrm{DO}$ concentrations under chronic $\mathrm{TiO}_{2} \mathrm{NP}$ exposure Fig. 4 Heat map images of the functional gene expressions related to amino acid (A) and RNA translation or ribosomal (B) metabolisms in the pre-exposure cells, 12-d, and 40-d $\mathrm{TiO}_{2}$ NP-impaired cells. ('*' indicates no statistical differences between the gene expressions compared to the pre-exposure cells, $\mathrm{p}>0.05$ or $|\mathrm{FC}|<1.0)$

Fig. 5 Differentially expressed functional genes related to inorganic ion transport and metabolism and cell membrane biogenesis after $12-\mathrm{d}$ and $40-\mathrm{d}$ exposure to $50 \mathrm{mg} / \mathrm{L} \mathrm{TiO}_{2} \mathrm{NPs}$; the pre-exposure cells are the reference $(\mathrm{p} \leq 0.05,|\mathrm{FC}| \geq 1.0)$.

Fig. 6 Differentially expressed functional genes encoding for energy production/conversion after 12- $\mathrm{d}$ and 40- $\mathrm{d}$ exposure to $50 \mathrm{mg} / \mathrm{L} \mathrm{TiO}_{2} \mathrm{NPs}$; the pre-exposure cells are the reference $(\mathrm{p} \leq 0.05$, $|\mathrm{FC}| \geq 1.0$ ). 
1 Table 1 Microarray and qRT-PCR analysis of selected functional genes after 12-d and 40-d

2 exposure to $50 \mathrm{mg} / \mathrm{L} \mathrm{TiO}_{2} \mathrm{NPs}$, respectively; the pre-exposure cells are the reference.

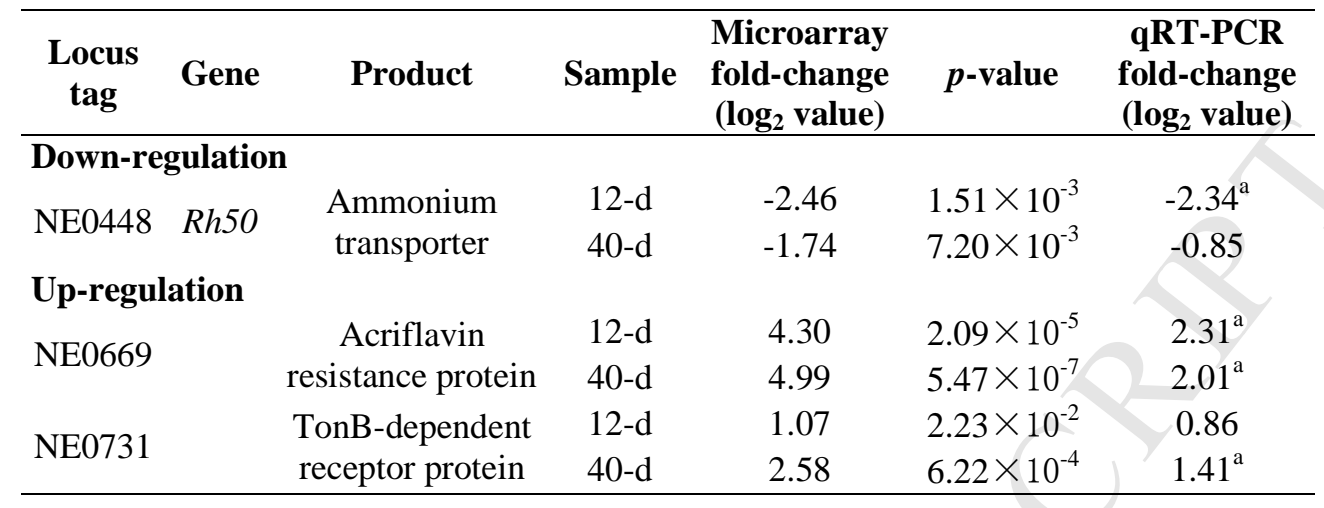


Table 2 Selected functional genes with significant transcriptional responses to $50 \mathrm{mg} / \mathrm{L} \mathrm{TiO} \mathrm{NPs}_{2}(|\mathrm{FC}| \geq 1, p \leq 0.05)$.

\begin{tabular}{|c|c|c|c|c|c|}
\hline \multirow{2}{*}{ Gene } & \multirow{2}{*}{$\begin{array}{l}\text { Locus_ } \\
\text { tag }\end{array}$} & \multirow{2}{*}{ Product } & \multirow{2}{*}{ Description } & \multicolumn{2}{|c|}{ FC ( $\log _{2}$ value $)$} \\
\hline & & & & Imp./Pre. & Rec./Pre. \\
\hline \multicolumn{6}{|c|}{ Toxin-antitoxin genes } \\
\hline & NE1563 & Hypothetical protein & Type II TA system, RelE/StbE-RelB/StbD & 1.17 & - \\
\hline & NE1584 & Hypothetical protein & Type II TA system, RelE/StbE-RelB/StbD & 1.04 & - \\
\hline mreB & NE2070 & Rod shape-determining protein MreB & Type II TA system-related factors & - & 1.88 \\
\hline \multicolumn{6}{|c|}{ ECF subfamily genes } \\
\hline & NE0547 & ECF subfamily RNA polymerase sigma factor & Transcription machinery, oxidative stress response & 1.05 & - \\
\hline & NE1041 & ECF subfamily RNA polymerase sigma-70 factor & Transcription machinery, oxidative stress response & 1.08 & 1.05 \\
\hline & NE1992 & ECF subfamily RNA polymerase sigma factor & Transcription machinery, oxidative stress response & 1.02 & - \\
\hline & NE1001 & ECF subfamily RNA polymerase sigma factor & Transcription machinery, oxidative stress response & - & 1.06 \\
\hline \multicolumn{6}{|c|}{ Thioredoxin gene } \\
\hline & NE1319 & Thioredoxin & Oxidative stress response & 1.26 & - \\
\hline \multicolumn{6}{|c|}{ DNA repair/replication genes } \\
\hline$r d g C$ & NE0507 & Recombination associated protein & DNA repair, double-strand breaks repair & 1.48 & 1.01 \\
\hline \multirow[t]{4}{*}{$s s b$} & NE2453 & Single-strand binding protein family & DNA repair, single-strand breaks repair & 1.37 & 2.12 \\
\hline & NE0098 & DnaA regulatory inactivator Hda & DNA replication & 1.02 & - \\
\hline & NE0001 & Chromosomal replication initiation protein & DNA replication, initiation factors & - & 1.50 \\
\hline & NE1850 & ATP-dependent DNA helicase RecG & DNA repair, double-strand breaks repair & - & 1.01 \\
\hline
\end{tabular}


Fig. 1

2

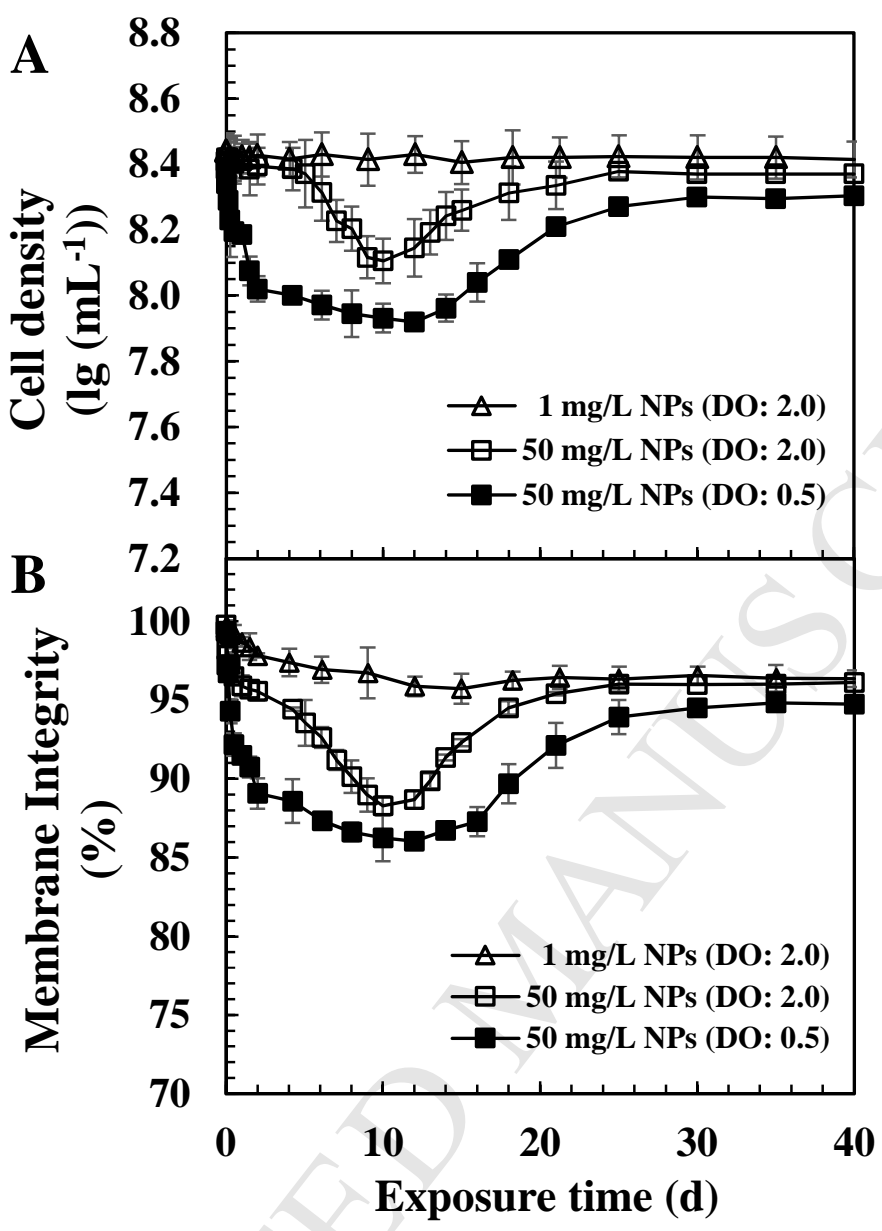


Fig. 2

6

7

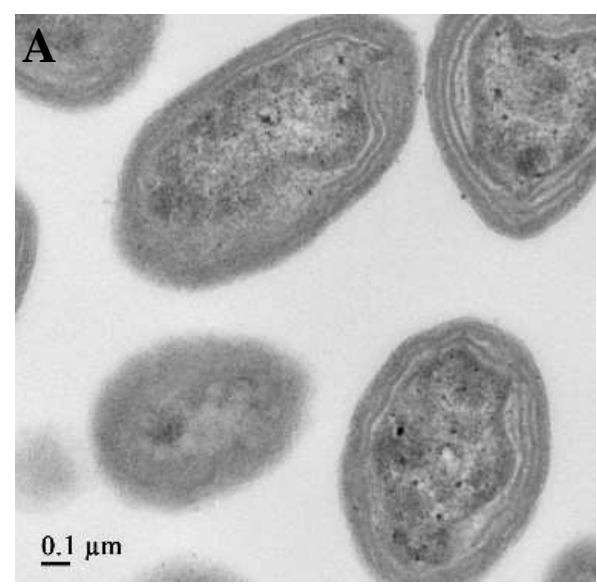

Pre-exposure

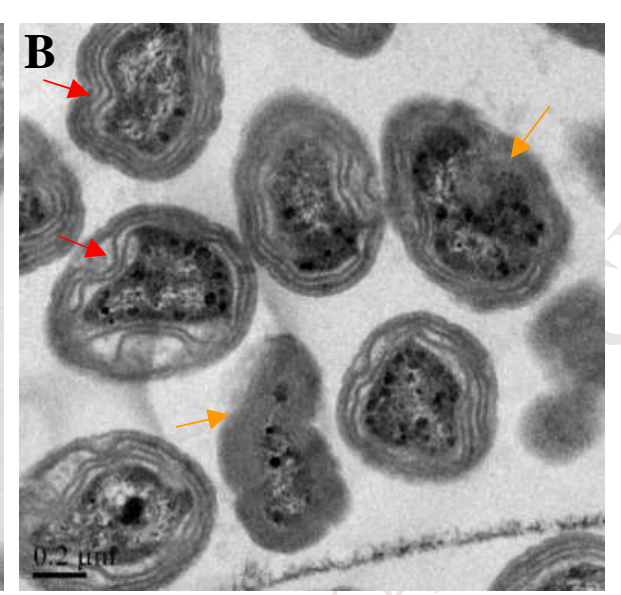

12-d exposure

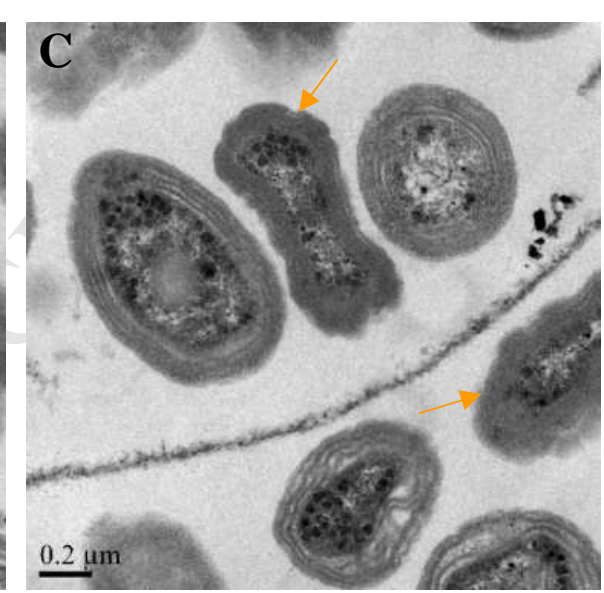

40-d exposure 
Fig. 3

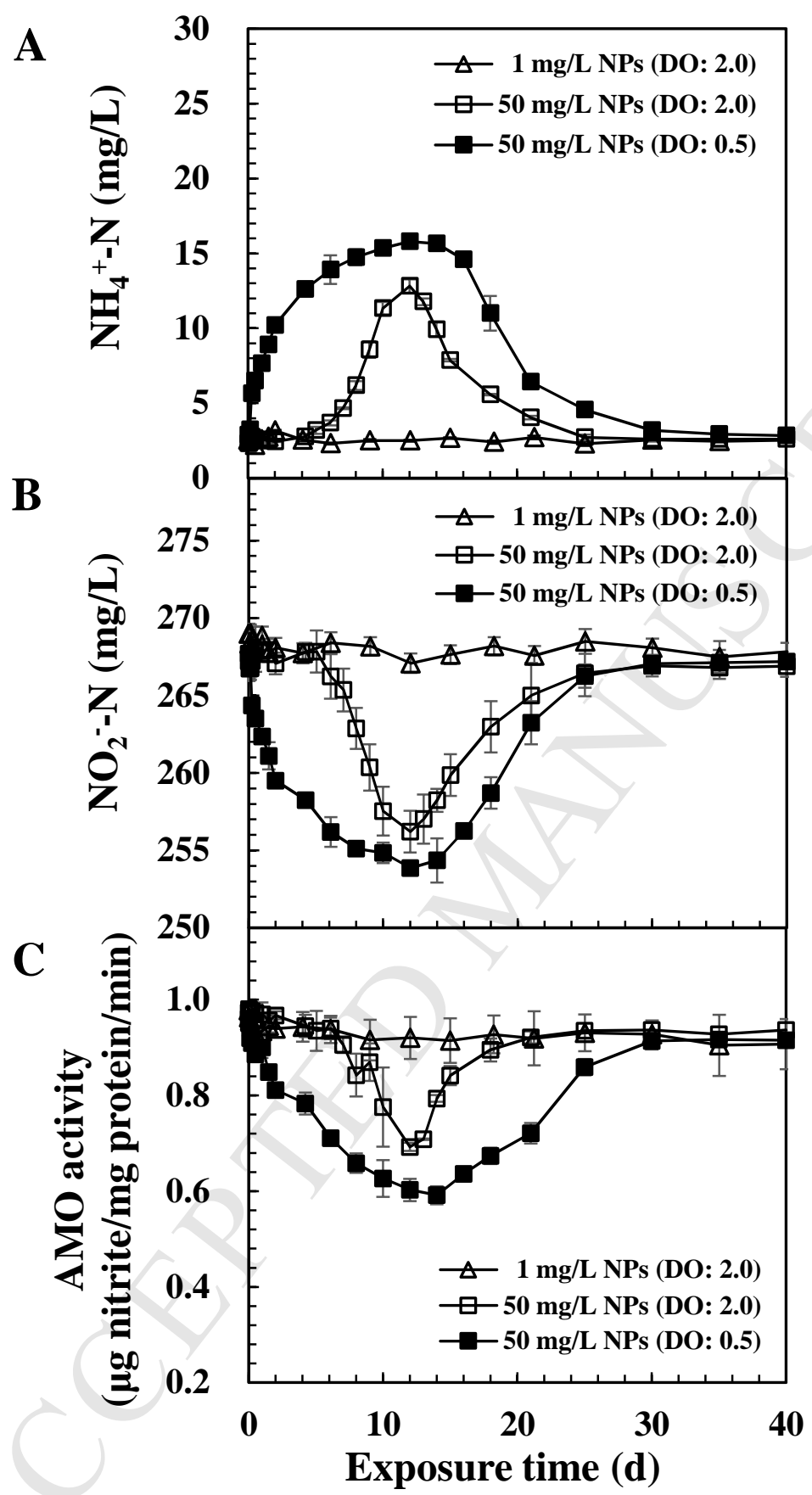


A

\section{Color Key}

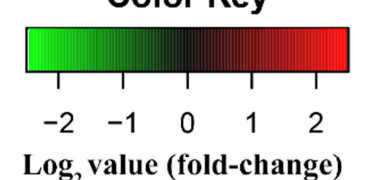

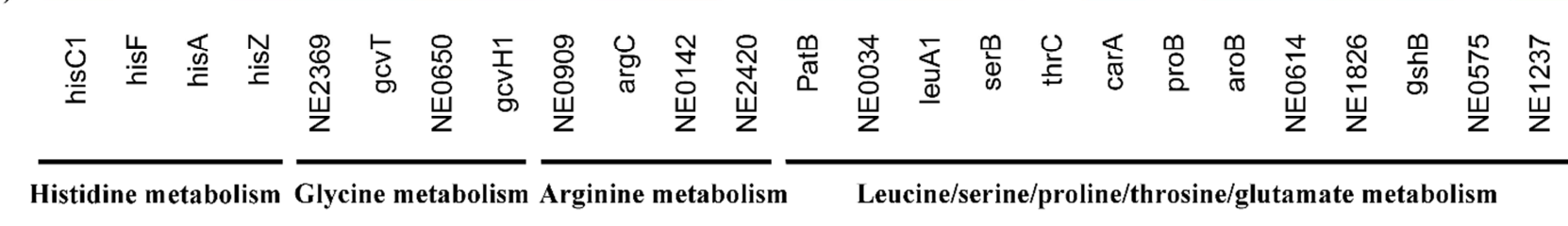

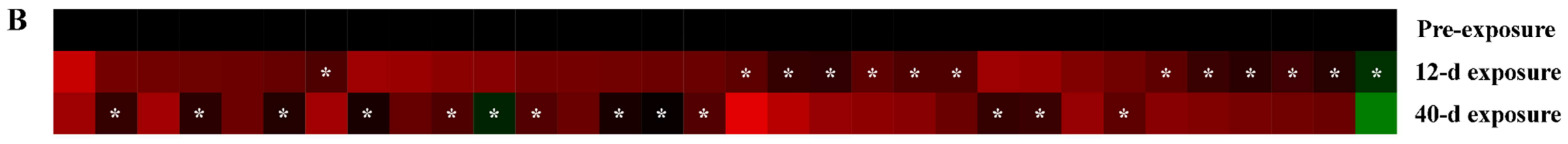

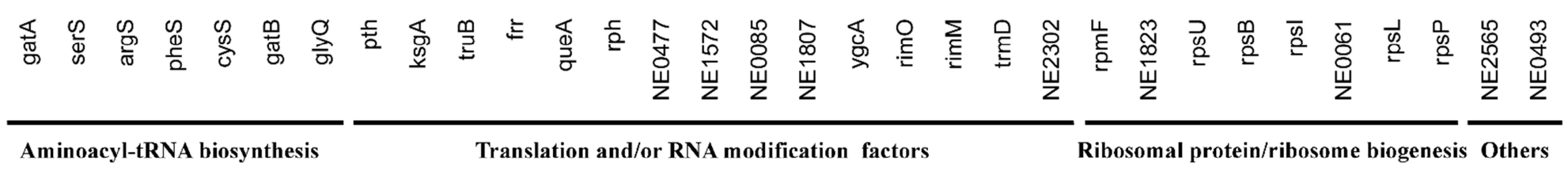


Fig. 5
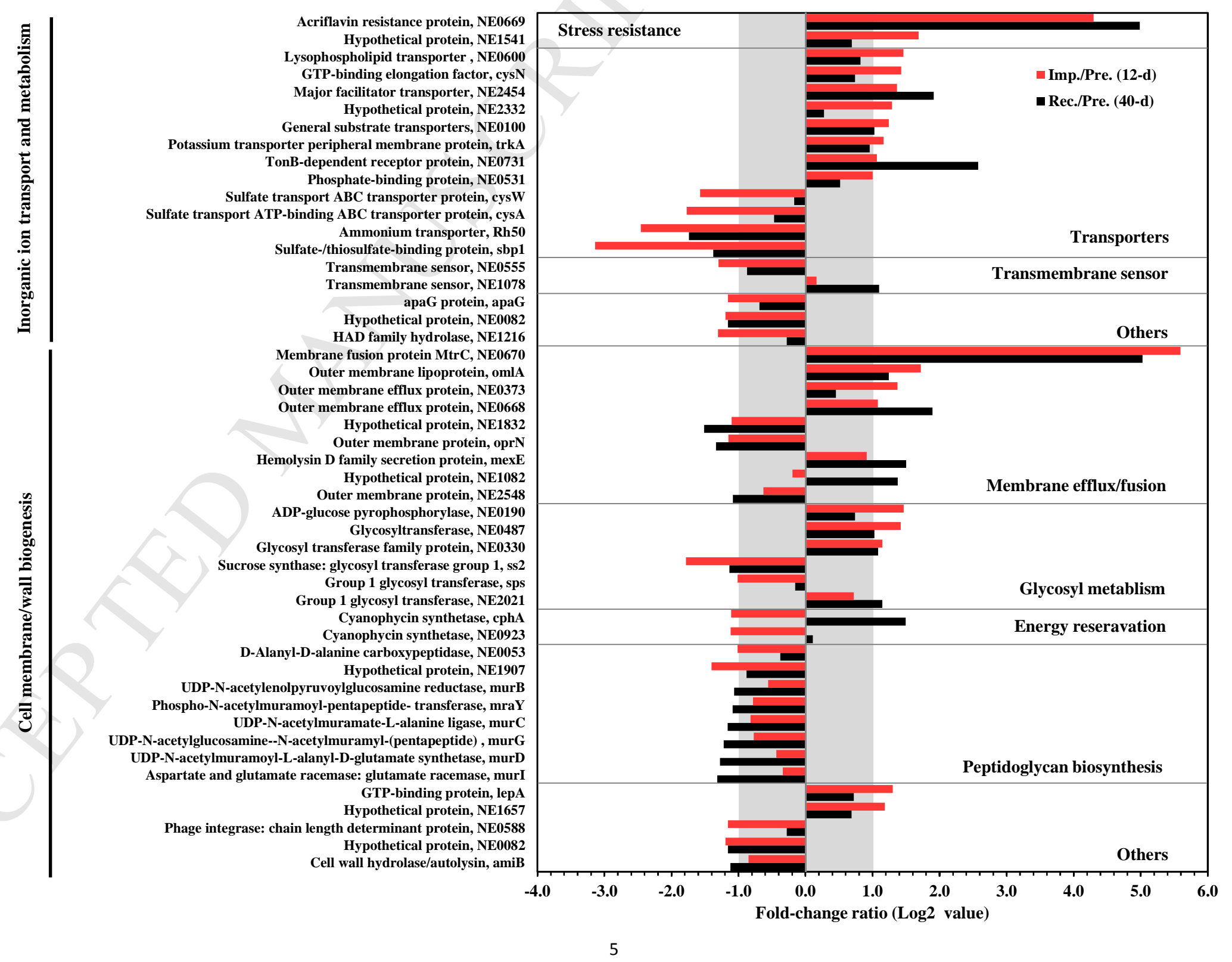
Fig. 6

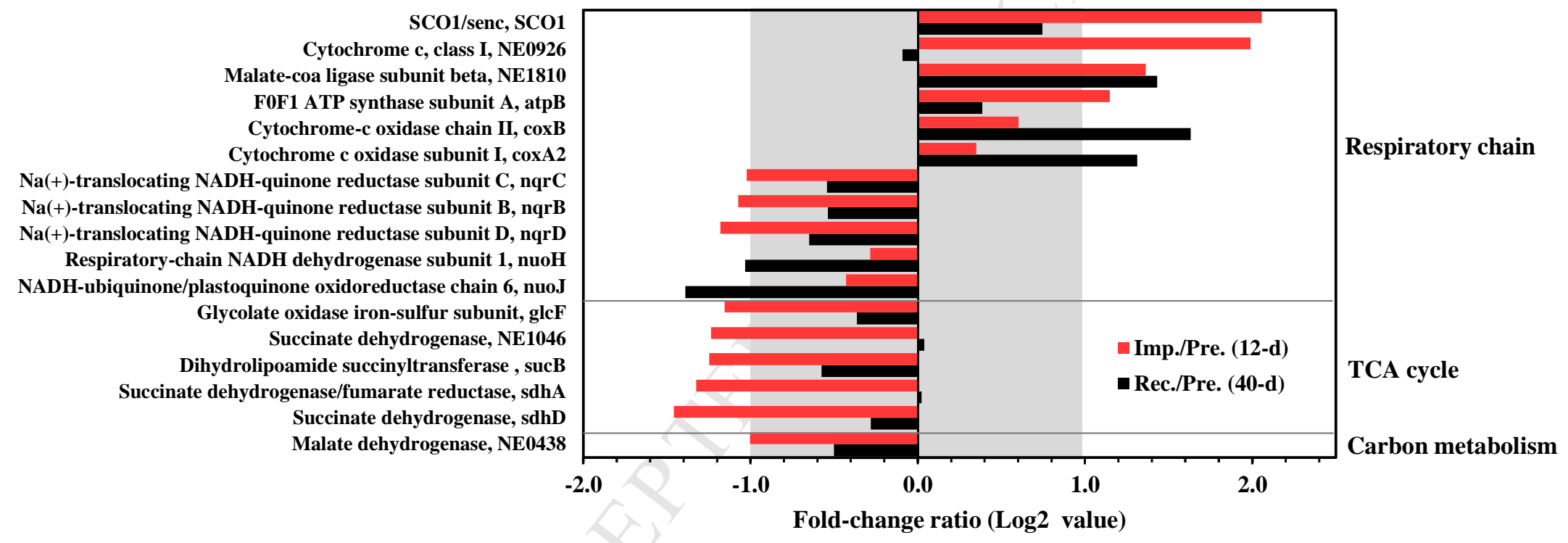




\section{Adaption and recovery of Nitrosomonas europaea to chronic $\mathrm{TiO}_{2}$ nanoparticle exposure}

\section{Research Highlights:}

- Cells adapted to chronic NP stress and all the metabolic activities recovered.

- Membrane repair associated regulations were pivotal for cellular adaption.

- Diverse metabolic and stress-defense pathways were activated for cell recovery.

- Low DO condition compromised NP impaired cells' resistance and adaption capacities.

- Stimulation limitation of respiratory chain accounted for the compromised capacity. 